\title{
BEBERAPA PARAMETER KIMIA YANG MEMPENGARUHI PERTUMBUHAN RUMPUT LAUT MERAH Kappaphycus alvarezii (DOTY) DI PERAIRAN LEBIH- DALAM
}

\section{SOME CHEMICAL PARAMETERS THAT INFLUENCE THE GROWTH OF RED SEAWEED Kappaphycus alvarezii (DOTY) IN DEEPER-WATER}

\author{
Petrus A. Wenno ${ }^{1}$, Rajuddin Syamsuddin ${ }^{2}$ and Magdalena Latuihamallo ${ }^{1}$ \\ ${ }^{1}$ Fakultas Perikanan dan Ilmu Kelautan, Universitas Pattimura, Ambon \\ ${ }^{2}$ Fakultas Ilmu Kelautan dan Perikanan, Universitas Hasanuddin, Makassar \\ Alamat korespodensi: petrawenno@gmail.com
}

\begin{abstract}
Abstrak : Secara konvesional, budi daya rumput laut memerlukan wilayah besar pada perairan dangkal, tetapi tidak semua air cocok untuk pembiakannya. Penelitian ini bertujuan untuk menguji pengaruh beberapa parameter kimia yang cocok untuk tumbuhnya ganggang merah Kappaphycus alvarezii di perairan laut dalam. Penelitian ini difasilitasi dengan beberapa rakit gantung yang ditempatkan secara diagonal, satu di bawah yang lain, pada kedalaman 100, 250, 400, 550 dan $700 \mathrm{~cm}$. Pemotongan tunas dari strain hijau dan coklat digunakan sebagai bibit awal dengan berat 50,100 dan $150 \mathrm{~g}$. Semua tunas diikat pada tali nilon dengan diameter $1 \mathrm{~mm}$ yang sudah diatur pada tali dengan diameter $5 \mathrm{~mm}$ yang kemudian akan ditempatkan horizontal pada rakit gantung. Ruang antara dua tali panjang dan dua rumpun rumput laut diatur pada jarak $25 \mathrm{~cm}$. Hasil penelitian menunjukkan bahwa sebagian besar dari laju pertumbuhan harian berkurang dengan meningkatnya kedalaman air. Rata-rata tertinggi dari laju pertumbuhan harian (DGR) dari kedua strain pada berat 100 g yaitu 5,28 \pm $0,24 \%$ untuk hijau dan $5,45 \pm 0,18 \%$ untuk cokelat. Analisis varians (ANOVA) dari DGR menunjukkan interaksi antara strain dan berat awal, antara strain dan kedalaman, dan antara berat awal dan kedalaman yang signifikan $(\mathrm{P}<0,01)$, namun antara strain, berat awal dan kedalaman tidak ada yang signifikan $(\mathrm{P}>0,05)$. Zat kimia yang berhubungan dengan DGR berdasarkan analisis regresi multivariat yaitu salinitas, $\mathrm{pH}$, amonium dan magnesium
\end{abstract}

Kata Kunci : Kappaphycus alvarezii, Rakit Gantung, Perairan dalam.

Abstract: Conventionally, culture seaweed requires large territory of shallow water, but not all water is suitable for culturing the plant. This study aims to examine the influence of some chemical parameters that are suitable for growing red alga Kappaphycus alvarezii in deeper-seawater. This research was facilitated with several hanging rafts which placed diagonally one below another at the depth of 100, 250, 400, 550 and $700 \mathrm{~cm}$. Cutting shoots of both green and brown strains were used as initial seeds, weight 50, 100 and $150 \mathrm{~g}$. All shoots were tied to $1 \mathrm{~mm}$ in diameter nylon string that already lined up at $5 \mathrm{~mm}$ in diameter longline rope that would then be placed horizontally on the hanging raft. The space between two long ropes and two seaweed clumps was arranged the same to $25 \mathrm{~cm}$ distance. The results showed that most of the daily growth rate was reduced by increasing water depth. The highest average of the daily growth rate (DGR) of both strains occurred at $100 \mathrm{~g}$ initial weight that was $5.28 \pm 0.24 \%$ for the green and $5.45 \pm 0.18 \%$ for the brown. Analysis of variance (ANOVA) of the DGR showed the interaction between strain and the initial weight, between strain and the depth, and between the initial weight and the depth that were significantly highest $(P<0.01)$, but was no significant $(P>0.05)$ among strain, the initial weight and the depth. Chemical substances that correlated to $D G R$ based on multivariate regression analysis were salinity, $\mathrm{pH}$, ammonium and magnesium.

Keywords: Kappaphycus alvarezii, Hanging raft, Deeper-water.

\section{PENDAHULUAN}

Budidaya rumput laut di perairan Indonesia makin berkembang luas sejak pertama kali diperkenalkan (Adnan dan Porse, 1987). Namun, kegiatan yang berlangsung terus-menerus di lokasi yang sama sepanjang tahun dapat menyebabkan pertumbuhan dan produksi biomassa menjadi rendah. Hasil penelitian menunjukkan bahwa produksi biomassa rumput laut secara vertikal (verticulture) dengan memanfaatkan kolom air lebih tinggi jika dibandingkan dengan sistem longline pada permukaan air (Hurtado dan Agbayani, 2002). Dengan sistem longline, produksi biomassa rumput laut yang dihasilkan di Indonesia hanya sebesar 30 ton/Ha per tahun atau 5 ton/Ha per panen (Dahuri, 2012). Sementara secara vertikal, setelah dikonversi dapat mencapai 120 ton/Ha per tahun (Hurtado dan Agbayani, 2002). Budidaya rumput laut secara vertikal dapat diterapkan dengan hasil panen tinggi, khususnya dengan memanfaatkan laut lepas (off- 
shore) yang selama ini belum optimal dimanfaatkan. Pemanfaatan perairan lebih-dalam sampai saat ini hanya terbatas untuk penelitian, sehingga membutuhkan lebih banyak upaya dan energi untuk menjadikannya sebagai lahan budidaya yang potensial.

Budidaya rumput laut $K$. alvarezii, belakangan ini telah dilakukan hampir di seluruh nusantara. Karena tidak membutuhkan biaya besar dan keterampilan khusus, maka kegiatan tersebut sering menimbulkan konflik antara pembudidaya lama dan pendatang baru yang ingin memanfaatkan lahan yang sama. Perairan dangkal dengan luas yang terbatas merupakan penyebab utama karena luasnya terbatas. Namun pemanfaatan perairan lebih-dalam memiliki kendala yang berhubungan dengan karakteristik bahan kimia, peralatan budidaya, lingkungan sekitar dan energi untuk menjadikannya bermanfaat. Sahoo dan Ohno (2003) mengemukakan bahwa air yang berasal dari perairan lebih-dalam kaya unsur hara jika dimanfaatkan sebagai media kultur di laboratorium maupun media budidaya untuk Kappaphycus dan jenis rumput laut lainnya.

Sebagai komoditas ekonomi penting, budidaya alga merah $K$. alvarezii membutuhkan lahan lebih luas untuk memenuhi permintaan pasar yang terus meningkat. Hal ini terlihat dari peningkatan usaha budidaya yang terus berlangsung hampir di seluruh daerah, sehingga mendorong pemerintah menetapkan pencapaian target produksi nasional 10 juta ton tahun 2014 (Nurdjana, 2010) yang sampai sekarang belum terpenuhi. Jenis rumput laut yang paling banyak dibudidaya merupakan sumber karaginan yang berasal dari kelompok eucheumatoid seperti Eucheuma denticulatum dan $K$. alvarezii. Dilain pihak hasil panen, produksi biomassa dan karaginan rumput laut dipengaruhi oleh laju pertumbuhan harian $(\mathrm{LPH})$.

Penelitian ini ditujukan untuk mengetahui parameter kimia yang mempengaruhi LPH rumput laut merah $K$. alvarezii di perairan lebih-dalam yang berkaitan dengan karakteristik kimia perairan dan unsur hara yang dibutuhkan untuk pertumbuhan.

\section{BAHAN DAN METODE Bahan Penelitian}

Penelitian ini menggunakan rumput laut merah Kappaphycus alvarezii strain hijau dan strain coklat yang diperoleh dari sentra produksi rumput laut Kabupaten Takalar. Rumput laut yang dijadikan bibit adalah tallus muda yang masih berbentuk kerucut (Neish, 2005). Untuk mempertahankan homogenitas, bibit diambil dari sumber yang sama, sedangkan untuk penentuan strain dilakukan menurut perbedaan warna tallus (Muñoz dkk., 2004). Hanya K. alvarezii strain hijau dan strain coklat yang digunakan.

\section{Lokasi Penelitian}

Penentuan lokasi penelitian tergantung pada kedalaman yang dibutuhkan, yaitu sebelah luar lokasi budidaya masyarakat lokal dengan kedalaman sekitar 9-10 m saat pasang. Hanya satu lokasi pada posisi geografis $5^{\circ} 13^{\prime} 58,1^{\prime \prime}$ LS dan $119^{\circ} 22^{\prime} 34,0^{\prime \prime}$ BT yang digunakan untuk penelitian dan terletak sekitar $600 \mathrm{~m}$ dari tepi pantai atau sebelah dalam alur pelayaran.

\section{Rancangan Penelitian}

Penelitian ini menggunakan rancangan faktorial acak kelompok (RAK) untuk evaluasi dampak interaksi perlakuan terhadap variabel tetap (Hanafiah, 2005). Penempatan perlakuan dan ulangan dilakukan secara acak tetapi lengkap terhadap satuan percobaan supaya tidak terjadi interaksi antara satuan percobaan. Faktor pertama adalah $K$. alvarezii strain hijau (S1) dan strain coklat (S2); faktor kedua adalah berat awal bibit $50 \mathrm{~g}$ (B1), $100 \mathrm{~g}$ (B2) dan $150 \mathrm{~g}$ (B3); dan faktor ketiga adalah kedalaman $100 \mathrm{~cm}$ (K1), $250 \mathrm{~cm}(\mathrm{~K} 2), 400 \mathrm{~cm}(\mathrm{~K} 3), 550 \mathrm{~cm}(\mathrm{~K} 4)$ dan $700 \mathrm{~cm}$ (K5). Ketiga faktor merupakan variabel bebas yang berpengaruh terhadap laju pertumbuhan harian (LPH) sebagai variabel tetap (Y).

\section{Peralatan Budidaya}

Penelitian ini menggunakan peralatan budidaya rakit gantung yang dirancang untuk ditempatkan di perairan lebih-dalam di pada kedalaman lebih tinggi daripada tinggi kolom air yang digunakan peralatan tersebut pada saat air surut. Konstruksi rakit terdiri dari kayu dan pralon berisi campuran beton sebagai pemberat untuk mempertahankan rakit tetap pada posisi di bawah air. Seluruh rakit disatukan dengan tali nilon diameter $10 \mathrm{~mm}$ yang ditempatkan di bagian bawah permukaan air dengan bantuan pelampung, dan tetap pada tempatnya dengan bantuan jangkar yang terbuat dari bantal pasir (Gambar 1).

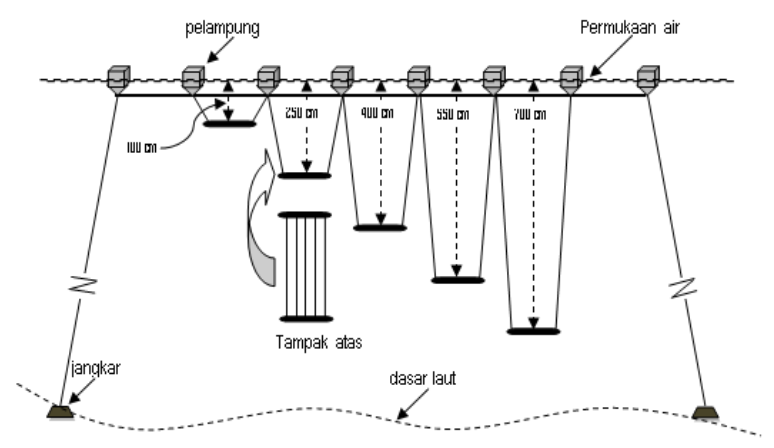

Gambar 1. Skema konstruksi peralatan budidaya rakit gantung untuk ditempatkan di perairan lebih-dalam (Sumber: Wenno, 2014)

\section{Pengukuran Variabel dan Analisis Data}

Tallus muda berumur empat minggu setelah melewati tahap aklimatisasi digunakan sebagai bibit karena memiliki banyak jaringan meristem. Setelah bibit ditanam dilakukan pengukuran penambahan berat tallus setiap minggu sampai panen.

Laju pertumbuhan harian (LPH) merupakan peningkatan berat rumput laut segar (FW, fresh weight) setiap minggu yang dihitung berdasarkan 
formula yang dikemukakan Ohno dkk. (1994), Wakibia dkk. (2006) dan Hung dkk. (2009) pada kedalaman berbeda.

$$
\mathrm{LPH}=(\mathrm{Bt} / \mathrm{Bo})^{1 / \mathrm{t}}-1 \times 100
$$

dimana: $\mathrm{LPH}=$ laju pertumbuhan harian $(\%) ; \mathrm{Bt}=$ $\mathrm{FW}$ rumput laut pada hari ke $\mathrm{t}$; $\mathrm{Bo}=\mathrm{FW}$ bibit rumput laut pada awal percobaan.

Analisis data dilakukan terhadap variabel tetap (Y). Hubungan antara variabel tetap dengan variabel kimia $\left(\mathrm{X}_{\mathrm{n}}\right)$ dilakukan menurut persamaan regresi linier berganda. Variabel bebas untuk parameter kimia air laut adalah salinitas $\left(\mathrm{X}_{1}\right)$, derajat keasaman $\mathrm{pH}\left(\mathrm{X}_{2}\right)$, amonium $\mathrm{NH}_{4}{ }^{+}\left(\mathrm{X}_{3}\right)$, nitrat $\mathrm{NO}_{3}^{-}\left(\mathrm{X}_{4}\right)$, fosfat $\mathrm{PO}_{4}{ }^{-}\left(\mathrm{X}_{5}\right)$, magnesium $\mathrm{Mg}\left(\mathrm{X}_{6}\right)$ dan kalsium $\mathrm{Ca}\left(\mathrm{X}_{7}\right)$. Analisis regresi berganda dilakukan menurut perlakuan kelompok.

Berdasarkan data hasil percobaan dirumuskan model matematika untuk rancangan acak kelompok (RAK) menurut formula yang dikemukakan Steel dan Torrie (1993), dan dinyatakan sebagai:

$$
\begin{gathered}
\mathrm{Yijkl}=\mu \\
(\alpha \beta \alpha) \mathrm{ijk}+\beta \mathrm{j}+\gamma \mathrm{k} \mathrm{k} \mathrm{kl}
\end{gathered}
$$

dimana: Yijkl merupakan data pengamatan; $\mu$ nilai tengah umum; $\alpha \mathrm{i}$ pengaruh perlakuan strain ke- $\mathrm{i} ; \beta \mathrm{j}$ pengaruh perlakuan berat awal ke- $\mathrm{j} ; \gamma \mathrm{k}$ pengaruh perlakuan kedalaman ke-k; $\alpha \beta, \alpha \gamma, \beta \gamma$ adalah interaksi antar faktor; cijkl galat acak; i $=1,2 ; \mathrm{j}=1,2,3 ; \mathrm{k}=$ $1,2,3,4,5$; dan $1=1,2,3$.

Selanjutnya, dilakukan ANOVA (Analisis varian) terhadap variabel tetap (Y), yaitu LPH untuk mengetahui pengaruh perlakuan dan interaksi antara perlakuan (strain, berat awal dan kedalaman) terhadap LPH K. alvarezii.

\section{HASIL DAN PEMBAHASAN}

Hasil Analisis Varian (ANOVA) laju pertumbuhan harian memperlihatkan interaksi antara strain (S) dan berat awal (B), strain (S) dan kedalaman (K), serta berat awal (B) dan kedalaman (K) yang berpengaruh sangat nyata $(\mathrm{P}<0,01)$, tetapi tidak berpengaruh nyata $(\mathrm{P}>0,05)$ oleh interaksi antara strain (S), berat awal (B) dan kedalaman (K) terhadap LPH. Hasil uji lanjut BNJ dirangkum pada Tabel 1.

Laju pertumbuhan harian tertinggi strain hijau dan strain coklat diperoleh pada berat awal $100 \mathrm{~g}$, dan cenderung sama. Hal ini berhubungan dengan kerapatan tallus (Hurtado dkk., 2008) yang menyebabkan pertumbuhan cepat dengan berat awal tersebut. Pada berat awal 100g laju pertumbuhan harian dipengaruhi oleh interaksi yang kompleks dari radiasi cahaya matahari, suhu, unsur hara dan pergerakan air (Santelices, 1999), menyebabkan penyerapan unsur hara lebih cepat jika dibandingkan dengan berat awal yang lain. Penyerapan unsur hara dipengaruhi oleh kerapatan tallus (Azanza-Corrale dkk. 1996). Laju pertumbuhan harian tertinggi strain hijau diperoleh dengan berat awal $100 \mathrm{~g}$ sebesar 2,8\%, dan terendah dengan berat awal $150 \mathrm{~g}(2,08 \%)$. Laju pertumbuhan harian tertinggi strain coklat diperoleh dengan berat awal $100 \mathrm{~g}(2,84 \%)$, dan terendah dengan berat awal 50g $(2,6 \%)$.

Laju pertumbuhan harian $K$. alvarezii strain hijau dan strain coklat pada kedalaman 100 dan $250 \mathrm{~cm}$ cenderung sama. Laju pertumbuhan harian strain hijau tertinggi yang sama diperoleh pada kedalaman rendah 100 dan $250 \mathrm{~cm}(2,55 \%)$, dan terendah pada kedalaman $700 \mathrm{~cm}(2,23 \%)$. Laju pertumbuhan harian strain coklat tertinggi yang sama diperoleh pada kedalaman 100 dan $250 \mathrm{~cm}(2,83 \%)$, dan terendah pada kedalaman $700 \mathrm{~cm}(2,57 \%)$.

Laju pertumbuhan harian tertinggi strain hijau dan strain coklat yang diperoleh pada kedalaman 100 dan $250 \mathrm{~cm}$ berhubungan dengan pergerakan air (Santelices, 1999). Pada kedalaman tersebut pergerakan air bersifat turbulen, sehingga dapat mengurangi ketebalan air lapisan perbatasan pada permukaan tallus yang tidak bercampur (Neish, 2005), sehingga penyerapan unsur hara pada kedalaman tersebut lebih cepat jika dibandingkan dengan pada kedalaman yang lain. Glenn dan Doty (1990) mengemukakan bahwa penyerapan unsur hara saat air mengalir cepat di antara tallus lebih tinggi untuk amonium pada kedalaman rendah daripada untuk nitrat pada kedalaman yang tinggi. Penyerapan amonium oleh rumput laut lebih penting daripada penyerapan nitrat (Dy dan Yap, 2001; Raikar dan Wafar, 2006).

Gambar 2 memperlihatkan laju pertumbuhan harian strain coklat yang lebih tinggi daripada strain hijau. Laju pertumbuhan harian strain hijau sebesar $5,72 \pm 0,47 \%$ sebagai hasil interaksi berat awal $100 \mathrm{~g}$ dan kedalaman $100 \mathrm{~cm}$ lebih tinggi daripada laju pertumbuhan harian strain coklat sebesar 5,61 \pm $0,46 \%$.

Penyerapan unsur hara berhubungan dengan struktur tallus $K$. alvarezii, dimana strain coklat memiliki tajuk lebih rimbun daripada strain hijau, menyebabkan penyerapan unsur hara oleh strain coklat lebih cepat daripada oleh strain hijau (Hurtado dkk., 2008). Namun, kerapatan tallus yang lebih rimbun daripada kerapatan tallus optimal seperti pada penelitian ini menyebabkan laju pertumbuhan harian berkurang. Hal ini diduga berhubungan dengan kesempatan tanaman memperoleh cahaya matahari untuk proses fotosintesis, dan jumlah unsur hara yang lebih sedikit pada rumpun yang padat.

Laju pertumbuhan harian $K$. alvarezii strain hijau sebesar 2,52-5,80\% dan strain coklat (4,43$5,45 \%$ ) yang diperoleh dengan metode ini berada antara 1,9-6,3\% (Glenn dan Doty, 1990). Laju pertumbuhan harian penelitian ini pada berbagai kedalaman lebih tinggi jika dibandingkan dengan temuan Adnan dan Porse (1987) sebesar 2,5-3,5\%; dan Hurtado-Ponce dkk. (1996) sebesar 2,3-4,2\%; tetapi lebih rendah daripada temuan Muñoz dkk. 
(2004) sebesar 6,5\%; dan Lim dan Porse (1981) sebesar 5,7\%. Menurut Ask dan Azanza (2002), laju pertumbuhan harian yang lebih tinggi daripada $3,4 \%$ cukup menguntungkan untuk usaha budidaya rumput laut $K$. alvarezii. Hubungan antara parameter kimia yang mempengaruhi laju pertumbuhan harian $K$. alvarezii strain hijau dan strain coklat dinyatakan berdasarkan persamaan regresi berganda yang disusun menurut kedalaman perairan.

Laju pertumbuhan harian $K$. alvarezii strain hijau pada kedalaman $100 \mathrm{~cm}$ dinyatakan sebagai $\mathrm{LPH}_{100}=-24,5+0,371$ salinitas $+4,19 \mathrm{pH}-118$ amonium $-2,02$ nitrat $-91,3$ fosfat $+0,00322$ magnesium - 0,0077 kalsium $\left(\mathrm{R}^{2}=98,6\right)$; pada kedalaman $400 \mathrm{~cm}$ sebagai $\mathrm{LPH}_{400}=2,4+1,27$ salinitas $-3,27 \mathrm{pH}+46,8$ amonium $-1,84$ nitrat 39,1 fosfat $+0,00365$ magnesium $-0,0116$ kalsium $\left(\mathrm{R}^{2}=98,7\right)$; dan pada kedalaman $700 \mathrm{~cm}$ sebagai $\mathrm{LPH}_{700}=-20,5+0,85$ salinitas $+0,56 \mathrm{pH}+62,4$ amonium $-1,34$ nitrat -41 fosfat $+0,00295$ magnesium - 0,00902 kalsium $\left(\mathrm{R}^{2}=98,8\right)$. Selanjutnya, laju pertumbuhan harian $K$. alvarezii strain coklat pada kedalaman $100 \mathrm{~cm}$ dinyatakan sebagai $\mathrm{LPH}_{100}=-27+0,939$ salinitas $+0,43 \mathrm{pH}+$ 1,4 amonium $-2,24$ nitrat $-14,5$ fosfat $+0,00386$ magnesium - 0,0131 kalsium $\left(\mathrm{R}^{2}=96,3\right)$; pada kedalaman $400 \mathrm{~cm}$ sebagai $\mathrm{LPH}_{400}=-1,89+0,185$ salinitas $+0,57 \mathrm{pH}+37,3$ amonium $-0,666$ nitrat 22 fosfat $+0,00115$ magnesium $-0,003$ kalsium $\left(\mathrm{R}^{2}\right.$ $=92,1)$; dan pada kedalaman $700 \mathrm{~cm}$ sebagai $\mathrm{LPH}_{700}$ $=2,29+0,709$ salinitas $-1,65 \mathrm{pH}+44,3$ amonium -
0,859 nitrat $-31,7$ fosfat $+0,00199$ magnesium 0,006 kalsium $\left(\mathrm{R}^{2}=99,6\right)$.

Terlihat bahwa keenam persamaan regresi berganda menunjukkan pola yang sama, yaitu memiliki koefisien determinasi sangat kuat (mendekati 1), artinya laju pertumbuhan harian sangat dipengaruhi oleh parameter kimia, dan berhubungan dengan nilai salinitas, $\mathrm{pH}$, amonium dan magnesium.

Rumput laut membutuhkan salinitas penuh 32$35 \%$ untuk memperoleh pertumbuhan optimal (Neish, 2005). Salinitas lebih rendah daripada salinitas penuh dapat menimbulkan penyakit ice-ice (Tisera dan Naguit, 2009), sebaliknya jika lebih tinggi dalam jangka panjang menyebabkan layu permanen (Jensen dan Salisbury, 1984). Penyerapan unsur hara oleh tanaman membutuhkan $\mathrm{pH}$ optimum sekalipun tersedia dalam jumlah cukup. Magnesium merupakan unsur esensial yang diperlukan tanaman untuk sintesis klorofil. Pada penelitian ini konsentrasi magnesium sekitar 1851,85 - 4254,25 $\mu \mathrm{g} / \mathrm{L}$. Sebagai pusat klorofil, magnesium penting untuk pertumbuhan. Kekurangan magnesium menimbulkan klorosis dan nekrosis pada tumbuhan hijau (Grundon, 1987). Rumput laut tidak menunjukkan gejala kekurangan magnesium, terutama pada kondisi salinitas penuh dengan ketersediaan minimal sebesar $1292 \mu \mathrm{g} / \mathrm{L}$ (Anonim, 2009). Kadar magnesium pada penelitian ini lebih tinggi dan menunjukkan bahwa lokasi penelitian cukup layak untuk budidaya rumput laut.

Tabel 1. Hasil uji lanjut BNJ laju pertumbuhan harian $K$. alvarezii berdasarkan perbedaan strain $\mathrm{S}$, berat awal (B) dan kedalaman $(\mathrm{K})$

\begin{tabular}{|c|c|c|c|}
\hline $\begin{array}{c}\text { Interaksi antara } \\
\text { perlakuan }\end{array}$ & $\begin{array}{c}\text { Nilai rata-rata } \\
(\%)\end{array}$ & $\begin{array}{c}\text { Interaksi antara } \\
\text { perlakuan }\end{array}$ & $\begin{array}{c}\text { Nilai rata-rata } \\
(\%)\end{array}$ \\
\hline $\mathrm{S}_{1}$ dan $\mathrm{B}_{2} *$ & $2,80^{\mathrm{a}}$ & $\mathrm{S}_{2}$ dan $\mathrm{B}_{2} *$ & $2,84^{\mathrm{a}}$ \\
\hline $\mathrm{S}_{1}$ dan $\mathrm{B}_{3}$ & $2,08^{\mathrm{e}}$ & $\mathrm{S}_{2}$ dan $\mathrm{B}_{1}$ & $2,60^{\mathrm{c}}$ \\
\hline $\mathrm{S}_{1}$ dan $\mathrm{K}_{1} *$ & $2,55^{\mathrm{c}}$ & $\mathrm{S}_{2}$ dan $\mathrm{K}_{1}$ * & $2,75^{\mathrm{ab}}$ \\
\hline $\mathrm{S}_{1}$ dan $\mathrm{K}_{2} *$ & $2,53^{\mathrm{cd}}$ & $\mathrm{S}_{2}$ dan $\mathrm{K}_{2} *$ & $2,83^{\mathrm{a}}$ \\
\hline $\mathrm{S}_{1}$ dan $\mathrm{K}_{5}$ & $2,23^{\mathrm{f}}$ & $\mathrm{S}_{2}$ dan $\mathrm{K}_{5}$ & $2,57^{\mathrm{c}}$ \\
\hline $\mathrm{B}_{1}$ dan $\mathrm{K}_{1} *$ & $2,60^{\mathrm{d}}$ & $\mathrm{B}_{2}$ dan $\mathrm{K}_{1} *$ & $2,88^{\mathrm{ab}}$ \\
\hline $\mathrm{B}_{1}$ dan $\mathrm{K}_{2} *$ & $2,65^{\mathrm{d}}$ & $\mathrm{B}_{2}$ dan $\mathrm{K}_{2} *$ & $2,92^{\mathrm{a}}$ \\
\hline $\mathrm{B}_{1}$ dan $\mathrm{K}_{3} *$ & $2,55^{\mathrm{de}}$ & $\mathrm{B}_{2}$ dan $\mathrm{K}_{3} *$ & $2,84^{\mathrm{ab}}$ \\
\hline $\mathrm{B}_{1}$ dan $\mathrm{K}_{5}$ & $2,28^{\mathrm{h}}$ & $\mathrm{B}_{2}$ dan $\mathrm{K}_{5}$ & $2,66^{\mathrm{cd}}$ \\
\hline $\mathrm{B}_{3}$ dan $\mathrm{K}_{1} *$ & $2,47^{\mathrm{f}}$ & - & - \\
\hline $\mathrm{B}_{3}$ dan $\mathrm{K}_{2} *$ & $2,47^{\text {ef }}$ & - & - \\
\hline $\mathrm{B}_{3}$ dan $\mathrm{K}_{3} *$ & $2,39^{f}$ & - & - \\
\hline $\mathrm{B}_{3}$ dan $\mathrm{K}_{5}$ & $2,27^{\mathrm{h}}$ & - & - \\
\hline
\end{tabular}


Hijau 50g $\square$ Coklat 50g $\square$ Hijau 100g $\square$ Coklat 100g $\square$ Hijau 150g $\square$ Coklat 150g

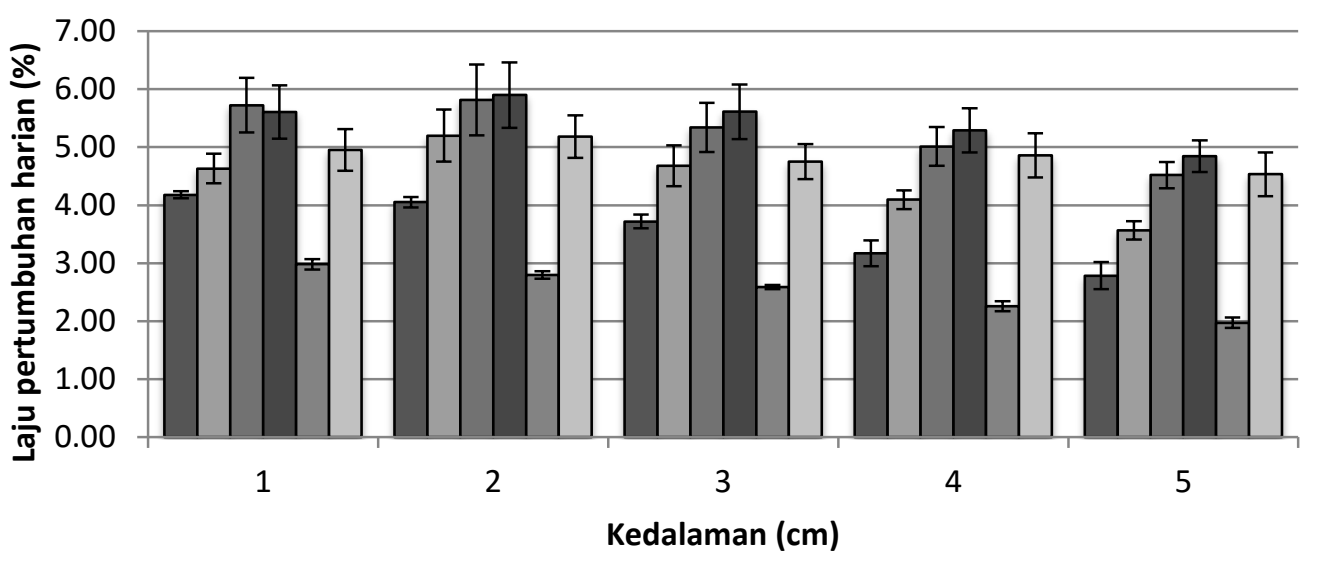

Gambar 2. Histogram laju pertumbuhan harian K. alvarezii strain hijau dan strain coklat menurut perbedaan berat awal dan kedalaman

\section{KESIMPULAN}

Laju pertumbuhan harian $K$. alvarezii strain hijau dan strain coklat ditentukan oleh perbedaan berat awal, tetapi pertumbuhan kedua strain cenderung berkurang menurut tingkat kedalaman. Hasil penelitian menunjukkan hubungan yang erat antara laju pertumbuhan harian dan ketersediaan unsur hara amonium dibandingkan nitrat, tetapi kehadiran nitrat juga penting untuk menjamin keseimbangan amonium dengan nitrit.

\section{DAFTAR PUSTAKA}

Adnan, H., and Porse, H., 1987. Culture of Eucheuma cottonii and Eucheuma spinosum in Indonesia. Hydrobiologia, 151/152: 355-358.

Anonim, 2009. Kumpulan Peraturan Pengendalian Pencemaran dan Kerusakan Pesisir \& Laut. Pusat pengelolaan Ekoregion Sulawesi, Maluku dan Papua, Kementerian Lingkungan Hidup

Ask, E.I., and Azanza, R., 2002. Advances in cultivation technology of commercial eucheumatoid species: A review with suggestions for future research. Aquaculture, 206: 257-277.

Azanza-Corrales, R., Aliaza, T.T., and Montano, N.E., 1996. Recruitment of Eucheuma and Kappaphycus on a farm in Tawi-Tawi, Philippines. Hidrobiologia, 326/327: 235-244.

Dahuri, R., 2012. Cetak Biru Pembangunan Kelautan dan Perikanan. Menuju Indonesia yang Maju, Adil-Makmur, dan Berdaulat. Roda Bahari, Bogor. 134 pp.

Dy, D.T. and Yap, H.T., 2001. Surge ammonium uptake of the cultured seaweed, Kappaphycus alvarezii (Doty) Doty (Rhodophyta, Gigartinales). J. Exp. Mar. Biol. Ecol. 265: 89100.

Glenn, E.P., and Doty, M.S., 1990. Growth of the seaweeds Kappaphycus alvarezii, K. striatum and Eucheuma denticulatum as affected by environment in Hawaii. Aquaculture, 84: 245255.

Grundon, N.J., 1987. Hungry crops: A Guide to Nutrient Deficiencies in Fields Crops. Queensland Department of Primary Industries. Brisbane, Australia.

Hanafiah, K.A., 2005. Rancangan Percobaan Aplikatip. Aplikasi Kondisional Bidang Pertanaman, Peternakan, Perikanan, Industri dan Hayati. Devisi Buku Perguruan Tinggi. PT Raja Grafindo Persada, Jakarta. xiii + 188 hal.

Hung, L.D., Hori, K., Nang, H.Q., Kha, T., and Hoa, L.T., 2009. Seasonal changes in growth rate, carrageenan yield and lectin content in the red alga Kappaphycus alvarezii cultivated in Camranh Bay, Vietnam. J. Appl. Phycol. 21: 265-272.

Hurtado, A.Q., Critchley, A.T., Trespoey, A., and Bleicher-Lhonneur, G., 2008. Growth and carrageenan quality of Kappaphycus striatum var. sacol grown at different stocking densities, duration of culture and depth. J. Appl. Phycol., 20: $551-555$

Hurtado, A.Q., and Agbayani, R.F., 2002. Deep-sea farming of Kappaphycus alvarezii using the multiple raft, long-line method. Bot. Mar., 45: 438-444.

Hurtado-Ponce, A.Q., Agbayani, R.F., Chavoso, E.A.J., 1996. Economics of Cultivating Kappaphycus alvarezii using fixed-bottom line and hanging-long line methods in Panagatan Cays, Caluya, Antique, Philippines. J. Appl. Phycol., 105: 105-109.

Jensen, W.A., and Salisbury, F.B., 1984. Botany, 2ed. Wadsworth, Belmont, Calif.

Lim, J.R., and Porse, H., 1981. Breakthrough in the commercial culture of Eucheuma spinosum in Northern Bohol, Philippines. In: Levring, T. (Ed.), Proceedings of the 10th International 
Seaweed Symposium. Walter de Grayter, Berlin, pp., 601-606.

Muñoz, J., Freile-Pelegrin, Y., and Robledo, D., 2004. Mariculture of Kappaphycus alvarezii (Rhodophyta, Solieriaceae) color stains in tropical waters of Yucatan, Mexico. Aquaculture 239: $161-177$.

Neish, I.C., 2005. The Eucheuma Seaplant Handbook Volume I. Agronomics, Biology and Crop System. SEAPlantNet Technical Monograph No. 0505-10A. Makassar.

Nurdjana, M.I., 2010. Program Peningkatan Produksi Ikan 353\% Periode 2010-2014. Makalah disajikan dalam Seminar Membangkitkan Kejayaan Indonesia sebagai Negara Maritim. Direktorat Jenderal Perikanan Budidaya Kementerian Kelautan dan Perikanan. Universitas Hasanuddin. 12 Januari 2010.

Ohno, M., Largo, D.B., and Ikumoto, T., 1994. Growth rate, carrageenan yield and gel properties of cultured kappa-carrageenan producing red alga Kappaphycus alvarezii (Doty) Doty in the subtropical waters of Shikoku, Japan. J. Appl. Phycol., 6 (1): 1-5.

Raikar, V., dan Wafar, M., 2006. Surge ammonium uptake in macroalgae from a coral atoll. Journal of Experimental Marine Biology and Ecology 339: $236-240$

Santelices, B., 1999. A conceptual framework for marine agronomy. Hydrobiologia, 398/399: 1523.

Sahoo, D., and Ohno, M., 2003. Culture of Kappaphycus alvarezii in deep seawater and Nitrogen enriched medium. Bull. Mar. Sci. Fish Kochi Univ., Vol. 22: 89-96.

Steel, R.G.D., dan Torrie, J.H., 1993. Prinsip dan Prosedur Statistika; Suatu Pendekatan Biometrik (Terjemahan Sumantri, B). Edisis ke-2. Jakarta, PT Gramedia Pustaka Utama.

Tisera, W.L., and Naguit, M.R.A., 2009. Ice-ice disease occurrence in seaweed farms in Bais Bay, Negros Oriental and Zamboanga Del Norte. The Treshold IV: 1-16.

Wakibia, J.G., Bolton, J.J., Keats, D.W., and Raitt, L.M., 2006. Factors influencing the growth rates of three commercial eucheumoids at coastal sites in southern Kenya. J. Appl. Phycol., 18: 565573.

Wenno, P.A., 2014. Analisis Pertumbuhan dan Kualitas Karaginan Alga Merah Kappaphycus alvarezii (Doty) Hasil Budidaya di Perairan Lebih-Dalam. Pascasarjana Universitas Hasanuddin, Makassar (Disertasi, tidak dipublikasikan). 